\title{
PENGARUH PENGAWETAN RENDAMAN DINGIN ASAM BORAT TERHADAP KUALITAS PAPAN DAN BINGKAI RENG KAYU AREN SEBAGAI BAHAN BANGUNAN
}

\section{EFFECT OF COLD IMMERSION PRESERVATION USING BORIC ACID TO THE QUALITY OF BOARD AND FRAME BATTEN OF AREN TRUNK AS BUILDING MATERIALS}

\author{
Petrus Patandung \\ Balai Riset dan Standardisasi Industri Manado \\ Jalan Diponegoro No.21-23 \\ Pos-el: patandungp@yahoo.com \\ Diterima Tanggal 24-3-2014, Disetujui Tanggal 8-4-2014
}

\begin{abstract}
ABSTRAK
Pengaruh pengawetan rendaman dingin dengan menggunakan asam borat terhadap papan dan bingkai reng kayu dari pohon aren yang tidak produktif untuk bahan bangunan telah dilakukan. Tujuan penelitian adalah untuk mengawetkan papan dan bingkai reng menggunakan asam borat sehingga dapat digunakan sebagai bahan bangunan. Penelitian dilakukan dengan membuat benda uji berbentuk papan dan bingkai reng dengan ukuran $2 \times 15 \times 15 \mathrm{~cm}$ dan $2,5 \times 12 \times 12 \mathrm{~cm}$ yang dibuat dari batang aren bagian keras dan bagian lunak yang diperoleh di kisaran: 0-1,5 ; 1,5-3,5; 3,5-6; dan 6-9 meter dari pangkal batang aren. Benda uji selanjutnya direndam secara dingin menggunakan asam borat 1,2, 4, 6 dan $8 \%$ selama 3 (tiga) bulan. Hasil analisis menunjukkan bahwa bagian keras contoh uji rendaman dingin memiliki kisaran kadar air 14,17-19,91\%, nilai berat jenis 0,46-0,66, kuat tekan sejajar serat $113-275 \mathrm{~kg} / \mathrm{cm}^{2}$, kuat tekan tegak lurus serat $100-123 \mathrm{~kg} / \mathrm{cm}^{2}$, retensi $0,66-6,65 \mathrm{~kg} / \mathrm{m}^{3}$, dan penetrasi $76,85-$ $81,68 \%$; dan bagian lunak memiliki kadar air 16,30-21,48\%, nilai berat jenis 0,24-0,38, kuat tekan sejajar serat $105-115 \mathrm{~kg} / \mathrm{cm}^{2}$, kuat tekan tegak lurus serat $75-110 \mathrm{~kg} / \mathrm{cm}^{2}$, retensi 0,29 $3,53 \mathrm{~kg} / \mathrm{m}^{3}$ dan penetrasi $67,88-71,93 \%$. Hasil penelitian menunjukkan bahwa perlakuan yang terbaik diperoleh pada benda uji I 0-1,5 meter dari pangkal batang aren dengan menggunakan bahan pengawet asam borat $8 \%$ karena menghasilkan kuat tekan sejajar serat sebesar 275 $\mathrm{kg} / \mathrm{cm}^{2}$ dan memenuhi standar mutu kayu bangunan SNI 03-3527-1994.
\end{abstract}

Kata kunci: pengawetan, kayu aren, papan dan bingkai reng, retensi, penetrasi

\section{ABSTRACT}

Study of the effect of cold immersion preservation using boric acid to the board and batten wood frame of a palm tree that is not productive for building materials has been carried out. The research objective is to preserve the board and batten frame using boric acid that can be used as building materials. Research carried out by making test specimen and frame-shaped board batten in size $2 \times 15 \times 15$ and 2,5x12×12 cm using hard parts and soft parts of palm trunks which were obtained in the height range from the base of the palm trunk of $0-1.5 ; 1.5$ to $3.5 ; 3.5$ to 6; and 6-9 meters. The test specimen was immersed in cold condition using boric acid with concentration of 1, 2, 4, 6 and $8 \%$ for 3 three months. Results showed that specimens using hard part immersed in cold condition had 14.17 to $19.91 \%$ moisture content, specific gravity value of 0.46 to 0.66 , compressive strength parallel to the fiber $113-275 \mathrm{~kg} / \mathrm{cm}^{2}$, compressive strength perpendicular to the fiber of $100-123 \mathrm{~kg} / \mathrm{cm}^{2}$, retention of 0.66 to $6.65 \mathrm{~kg} / \mathrm{m}^{3}$, and penetration of $76.85-81.68 \%$. On the other hand, specimens using soft parts immersed in cold condition had a moisture content of $16.30-21.48 \%$, with a 0.24 to 0.38 specific gravity value, compressive strength parallel to the fiber of $105-115 \mathrm{~kg} / \mathrm{cm}^{2}$, the compressive strength perpendicular to the fiber of $75-110 \mathrm{~kg} / \mathrm{cm}^{2}$, retention of 0.29 to $3.53 \mathrm{~kg} / \mathrm{m}^{3}$ and penetration of $67.88-71.93 \%$. The results showed that the best treatment was obtained on the test object of 0 - 
1.5 meters from the base of palm trunks using $8 \%$ boric acid which meet the quality standard of ISO timber No.03-3527-1994.

Keywords: board and batten frame, palm wood, penetration, preservation, retention.

\section{PENDAHULUAN}

\section{Latar Belakang}

\section{Pohon aren (Arenga pinnnata Merr)} merupakan tanaman suku palmae yang tersebar dihampir seluruh wilayah Indonesia, terutama terdapat di 14 provinsi, seperti Papua, Sulawesi Utara, Sulawesi Selatan, Sulawesi Tenggara, Bengkulu, Kalimantan Selatan dan Nangro Aceh Darussalam dengan total luas sekitar $60.482 \mathrm{Ha}$ (1). Sedangkan untuk Sulawesi Utara adalah $5.787 \mathrm{Ha}$ dengan total poroduksi sebanyak $16.834,47$ ton Sulut dalam Angka (2). Tanaman aren merupakan salah jenis tanaman palmae yang tumbuhnya memerluhkan udara tropis seperti Indonesia, yang penggunaannya hampir sama dengan pohon kelapa, yang seluruh bagiannya dapat diolah menjadi bahan industri yaitu : akar, daun, buah, ijuk dan batangnya yang jika dimanfaatkan secara maksimal akan mampu mengangkat tarap hidup petani aren. Bagian batangnya diolah sedemikian rupa menjadi produk industri seperti pemanfaatannya menjadi bahan bangunan, pohon aren adalah termasuk tanaman manocotyl, tidak mempunyai selubung kambiun,yang mana batang aren yang sudah besar berukuran tebal yang tetap, dan yang masih mudah itu baru kelihatan jelas kalau pohon aren berumur 2 sampai 3 tahun, pada umur tersebut batang aren kelihatan bertambah besar dan tebal yang tetap.Bagian pangkal batang aren kelihatan bertambah besar ini disebabkan terdorongnya akar-akar secara berangsur-angsur keluar sehingga bagian pangkal batang terus bertambah tebal (3). Pohon aren jika diusahakan atau diolah dengan baik dan benar akan menghasilkan sebanyak 60 jenis produk yang bernilai ekonomis antara lain nira aren, minuman beralkohol, nata de aren, gula semut, gula batu, kolang kalong, tali ijuk, sapu ijuk,bahan pengisi untuk jok kerajinan dari ijuk, bahan bangunan dari batang yaitu papan, balok dan bingkai reng, dari bahan tersebut perlu dilakukan pengawetan agar dapat memperpanjang daya pamakaiannya (4).

Perkembangan bahan bangunan di Indonesia khususnya bahan organik seperti kayu, mempunyai banyak kendala baik dari keberadaan atau ketersediaan maupun kualitasnya dimasa akan datang. Kebutuhan kayu sebagai bahan baku untuk indutri pengolahan kayu ternyata menurun drstis, sehingga banyak pabrik pengolahan kayu bangkrut karena kekurangan bahan baku. Beberapa produksi bahan bangunan sebagai alternatif untuk mengganti kayu sebagai komponen struktur dan non struktur telah banyak diproduksi seperti baja ringan ( light weight steel), aluminium , polivinilchlorida, tetapi harga masih menjadi kendala sehingga tidak terjangkau oleh masyarakat golongan menengah kebawah bahkan untuk rumah yang dibangun secara massal belum dapat menurunkan harga jual rumah.Keadaan ini akan terus berlangsung selama kebutuhan kayu terus meningkat 
seiring dengan perumahan baik dipedesaan maupun diperkotaan. Kayu sebagai bahan konstruksi bangunan sudah lama dikenal dan banyak dipakai sebelum orang mengenal beton dan baja. Pemakaian kayu harus mempunyai syarat yaitu mampu menahan beban, ketahanan dan keawetan serta mempunyai panjang, tebal dan kelas kekuatan serta umur sesuai dengan pemakaiannya. Adapun syarat mutu kayu bangunan dapat dilihat pada Tabel 1 dan 2 .

\section{Syarat Mutu Kayu Bangunan}

Mutu kayu bangunan dapat ditentukan dengan beberapa kriteria atau parameter yaitu; kekuatan, kelas awet, ukuran (lebar dan tebal) dapat dilihat pada Tabel 1 dan 2 sebagai pembanding SNI 033527-1994.

Tabel 1. Syarat Mutu Kekuatan Kayu Bangunan

\begin{tabular}{ccccccc}
\hline Kelas kuat & Berat Jenis & $\begin{array}{c}\text { Modulus } \\
\text { elastic } \\
\text { (ribuan) } \\
\mathrm{Kg} / \mathrm{cm}^{2}\end{array}$ & $\begin{array}{c}\text { Tekan } \\
\text { sejajar } \\
\text { serat/Kg/cm }\end{array}$ & $\begin{array}{c}\text { Tekan } \\
\text { tegak } \\
\text { lurus } \\
\text { serat } \\
\mathrm{kg} / \mathrm{cm}^{2}\end{array}$ & $\begin{array}{c}\text { Lentur } \\
\text { Patah } \\
\mathrm{kg} / \mathrm{cm}^{2}\end{array}$ & $\begin{array}{c}\text { Geser } \\
\text { sejajar } \\
\text { serat } \\
\mathrm{Kg} / \mathrm{cm}^{2}\end{array}$ \\
\hline I & $\geq 0,9$ & $\leq 161$ & $\geq 630$ & $\geq 171$ & $\geq 221$ & $\geq 93$ \\
II & $0,6-0,9$ & 112 & 411 & 114 & 795 & 59 \\
III & $06-0,6$ & 75 & 266 & 76 & 437 & 37 \\
IV & $0,3-0,4$ & 56 & 193 & 57 & 278 & 26 \\
V & $\leq 0,3$ & $\geq 56$ & $\leq 193$ & $\leq 57$ & $\leq 278$ & $\leq 26$ \\
\hline
\end{tabular}

Tabel 2. Ukuran Lebar dan Tebal Kayu Bangunan

\begin{tabular}{|c|c|c|c|}
\hline No & Jenis Penggunaan & Tebal $(\mathrm{Cm})$ & Lebar $(\mathrm{Cm})$ \\
\hline & & 1,5 & 3456781012151820 \\
\hline \multirow[t]{2}{*}{1} & Lis dan Jasuli & 1 & 13456 \\
\hline & & 2 & 45681012 \\
\hline \multirow[t]{5}{*}{2} & Papan & 2 & 1518202225 \\
\hline & & 2,5 & 151820222530 \\
\hline & & 3 & 1820222530 \\
\hline & & 3,5 & 1820222530 \\
\hline & & 4 & 18222530 \\
\hline \multirow[t]{5}{*}{3} & Bingkai reng dan kaso & 2,5 & 34681012 \\
\hline & & 3 & 4568101215 \\
\hline & & 3,5 & 3468101215 \\
\hline & & 4 & 68101215 \\
\hline & & 5 & 78101218 \\
\hline 4 & Balok & 6 & 81012131518202225 \\
\hline
\end{tabular}


Tujuan penelitian adalah melakukan pengawetan dengan metode rendaman dingin yang menggunakan asam borat terhadap papan dan bingkai reng batang aren yang tidak produktif untuk menjadi bahan bangunan.

\section{METODOLOGI PENELITIAN}

\section{Bahan dan Alat}

Bahan yang digunakan yaitu limbah batang aren, asam borat, $\mathrm{HCl}$, dan asam salisilat. Peralatan yang digunakan yaitu mistar ukur, gergaji, kapak, parang, drum, ember plastik (ukuran besar dan kecil), loyang plastik (ukuran besar dan kecil), kertas millimeter blok, kompor minyak tanah dan alat kuat tekan modifikasi Balai

\section{Metode Penelitian}

Penelitian ini dilakukan melalui metode percobaan pembuatan papan dan bingkai reng dengan menganalisis data secara deskriptif. Penelitian dilakukan melalui 2 (dua) tahap penelitian, yaitu:
Riset dan Industri Manado yang dilengkapi dengan dongkrak secara hidrolik yang kuat tekan $0-600 \mathrm{~kg} / \mathrm{cm}^{2}$

\section{Tempat Pelaksanaan Penelitian}

Penelitian dilaksanakan di Balai Riset dan Standardisasi Industri Manado, selama 10 (sepuluh) bulan mulai dari bulan Pebruari sampai dengan bulan November 2013.

\section{Tahap I Klassifikasi dan Konversi Batang Kayu Aren}

Klassifikasi batang kayu aren batang aren yang digunakan dalam penelitian memiliki diameter $40 \mathrm{~cm}$ dan tinggi $9 \mathrm{~m}$ dan diklasifikasikan menjadi 2 bagian berdasarkan kekerasannya, yaitu:

Bagian Lunak yang merupakan bagian yang memiliki area dengan diameter 0-30 $\mathrm{cm}$ dari titik tengah batang kayu aren. Bagian keras yang merupakan bagian yang memiliki area dengan diameter $30-40 \mathrm{~cm}$ dari titik tengah batang kayu aren dapat dilihat pada Gambar 1.

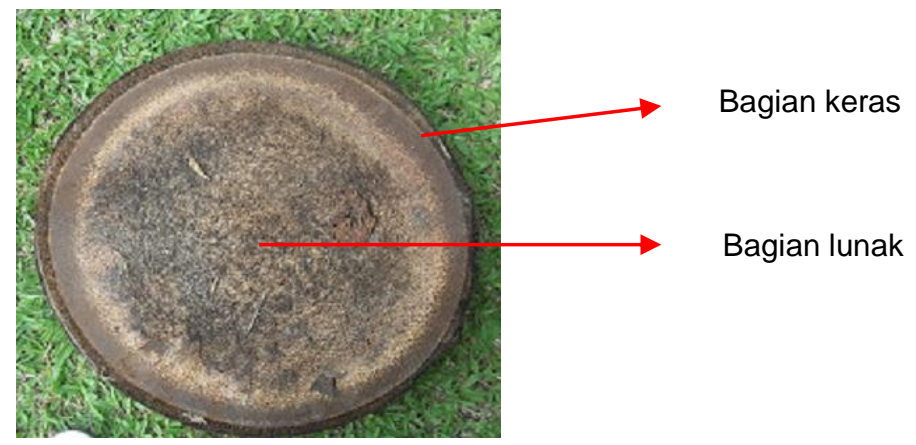

Gambar 1. Bagian batang aren terhadap bagian keras dan lunak 
Kemudian untuk pengujian dalam penelitian ini, bagian lunak dan bagian keras batang kayu aren di bagi menjadi 4 bagian berdasarkan panjang: Bagian I yaitu bagian yang memiliki ukuran 0-1,5 m dihitung dari pangkal batang kayu aren. Bagian II yaitu bagian yang memiliki ukuran 1,5-3,5 m dihitung dari pangkal batang kayu aren. Bagian III yaitu bagian yang memiliki ukuran 3,5-6,0 m dihitung dari pangkal batang kayu aren. Bagian IV yaitu bagian yang memiliki ukuran 6,0-9,0 m dihitung dari pangkal batang kayu aren. Konversi batang kayu aren. Setiap bagian batang kayu aren; Bagian Lunak I,II,III,IV dan bagian Keras I,II,III,IV; dikonversi menjadi papan dan bingkai reng, kemudian dibuat benda uji dengan dimensi papan $2 \times 15 \times 15$

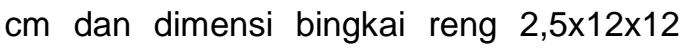
$\mathrm{cm}$. Papan dan bingkai reng yang diperoleh dijadikan contoh uji pada penelitian ini.

\section{Tahap II Pengawetan}

Pengawetan rendaman dingin
adalah suatu metode pengawetan bahan

\section{HASIL DAN PEMBAHASAN}

Hasil penelitian pengawetan papan dan bingkai reng dari kayu batang aren yaitu merupakan hasil klassifikasi dari pohon aren yang tidak produktif, kemudian diawetkan dengan menggunakan bahan pengawet asam borat secara dingin.Adapun contoh uji papan dan bingkai reng batang aren yang telah diawetkan dapat dilihat pada Gambar 2. Data dianalisis secara grafik. bangunan yang berbentuk papan, bingkai reng, balok dan bahan lainnya kemudian bahan tersebut disusun dalam suatu wadah tertentu lalu direndam beberapa jam atau hari, minggu dan bulan dengan maksud agar distribusi merata kepermukaan bahan yang akan diawetkan (5).

Papan dan bingkai reng atau contoh benda direndam dalam uji batang aren drum pengawetan yang telah berisi bahan pengawet dengan konsentrasinya yaitu sesuai dengan perlakuan konsentrasi bahan pengawet. Kemudian direndam selama 3 (tiga) bulan lalu diangkat dan disusun dalam ruangan terlindung selama 10-15 hari kemudian dianalisis (6).

\section{Parameter Uji}

Parameter yang diuji, yaitu: pengamatan secara visual (jamur, serangga serta kenampakan) kadar air, kuat tekan sejar serat, kuat tekan tegak lurus serat, berat jenis, penetrasi dan retensi dan, Standar Nasional Indonesia, 03-5010-1999 (7).

\section{Hasil Analisis Contoh Uji Batang Aren}

Setelah penyimpanan selama satu 2 minggu atau 15 hari diperoleh hasil pengamatan visual bagian tengah contoh uji batang aren belum mengalami penjamuran dan dirusak oleh rayap, begitu juga bagian pinggir contoh uji belum mengalami kerusakan oleh rayap. 

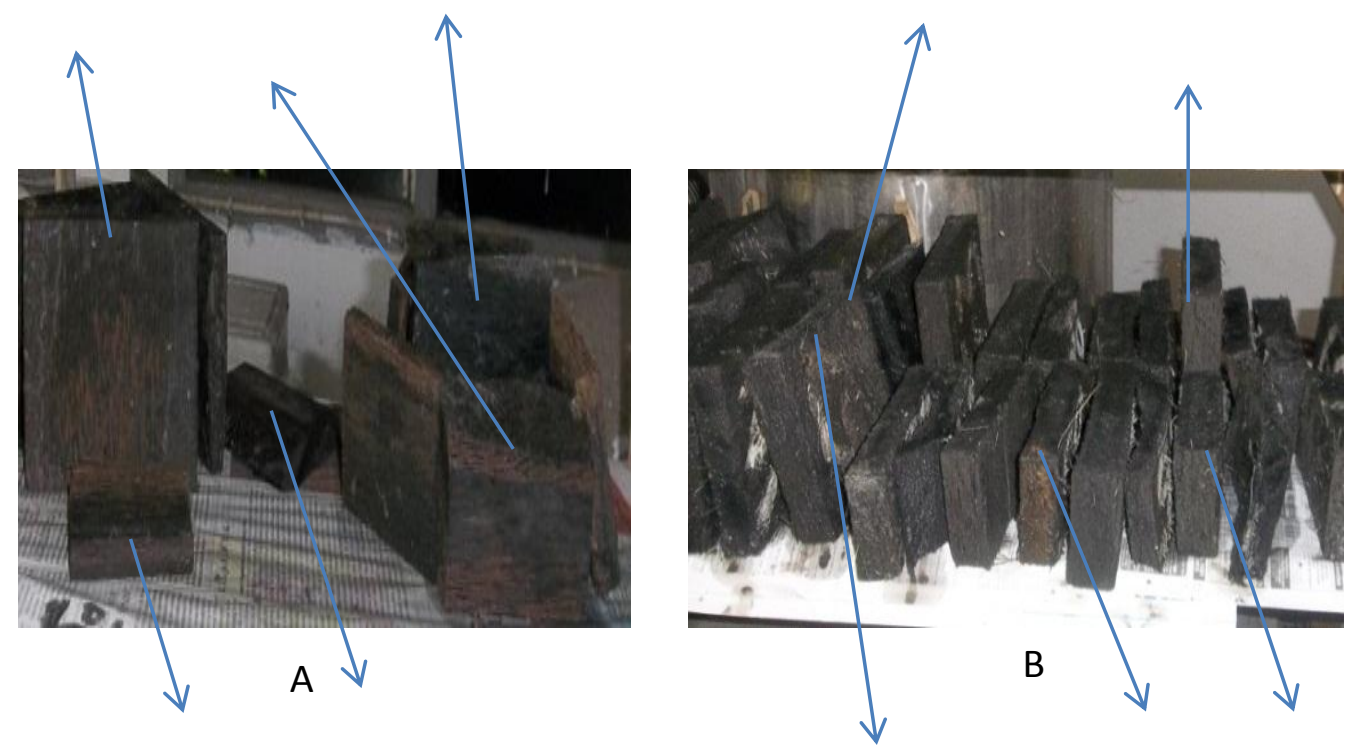

Gambar 2. Contoh Uji batang aren (A) papan dari bagian keras, (B) bingkai reng dari bagian lunak

\section{Analisis data}

Data dianalisis secara deskriptif berdasarkan pengaruh konsentrasi asam borat yang digunakan dalam pengawetan rendaman dingin terhadap kualitas papan dan bingkai reng kayu aren.

\section{Bagian Keras}

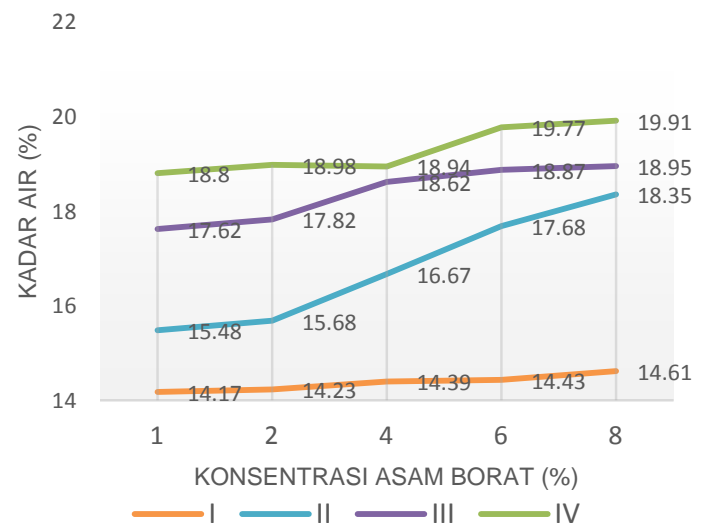

A

\section{Kadar Air}

Hasil analisis kadar air contoh uji papan dan bingkai reng batang aren yang menggunakan bahan pengawet asam borat dengan rendaman dingin dapat dilihat pada Gambar 3.

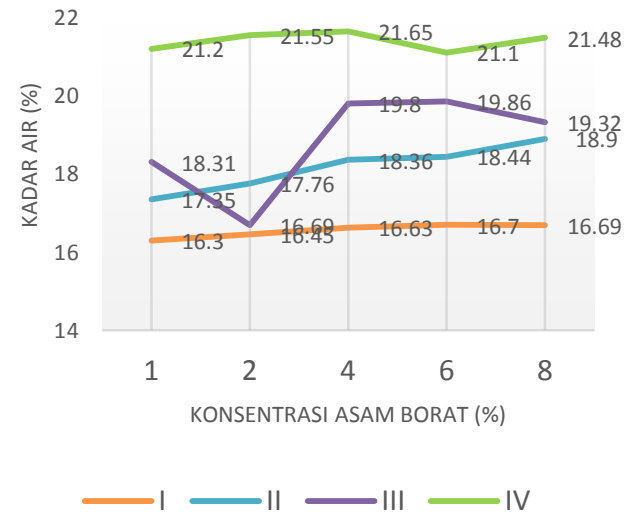

B

Gambar. 3 Pengaruh Konsentrasi Asam Borat sebagai bahan perendam terhadap kadar air papan dan bingkai reng dari (A) bagian keras kayu aren (\%), (B) bagian lunak kayu aren (\%) 
Hasil analisis kadar air contoh uji papan dan bingkai reng batang aren yang menggunakan bahan pengawetan asam borat dengan rendaman dingin (Gambar 3) menunjukkan bahwa bagian keras hasil kadar air yang tertinggi diperoleh pada contoh uji IV dengan ukuran panjang 3 meter atau 6-9 meter dari pangkal batang aren dengan menggunakan bahan pengawet $8 \%$ yaitu sebesar $19,91 \%$ dan yang terendah diperoleh pada contoh uji I dengan ukuran panjang 1,5 meter dari pangkal batang dengan konsentrasi bahan pengawet asam borat $1 \%$ yaitu sebesar $14,17 \%$ dan bagian lunak hasil kadar air yang tertinggi diperoleh pada contoh uji IV dengan ukuran panjang 3 meter atau 6-9 meter dari pangkal batang aren yaitu

\section{Bagian Keras}

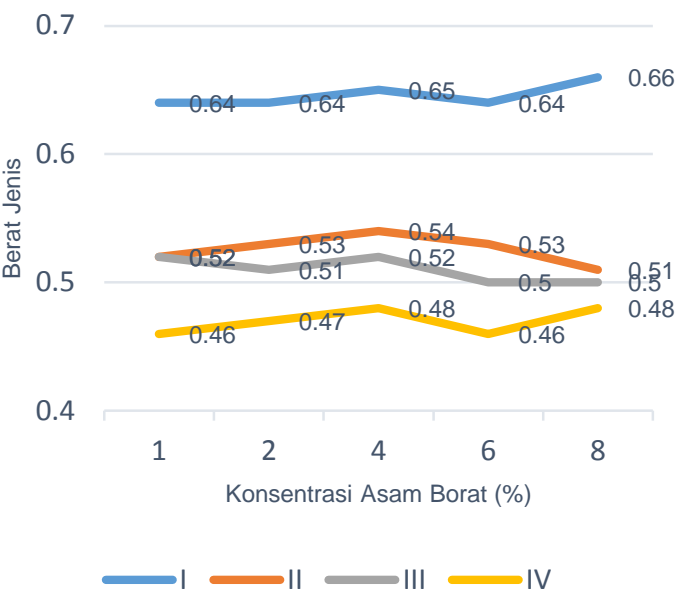

A sebesar $21,48 \%$ dan yang terendah diperoleh pada contoh uji I dengan ukran panjang 1,5 meter dari pangkal batang aren yaitu sebesar $16,30 \%$.

Hasil kadar air yang didapat terus meningkat disebabkan oleh struktur atau susunan serat contoh uji batang aren yang mana semakin keujung batang aren semakin lunak sehingga semakin cepat air meresap kedalam dinding selulosa dari batang (8).

\section{Berat Jenis}

Hasil analisis berat jenis contoh uji papan dan bingkai reng batang aren yang menggunakan bahan pengawet asam borat dengan rendaman dingin dapat dilihat pada Gambar 4.

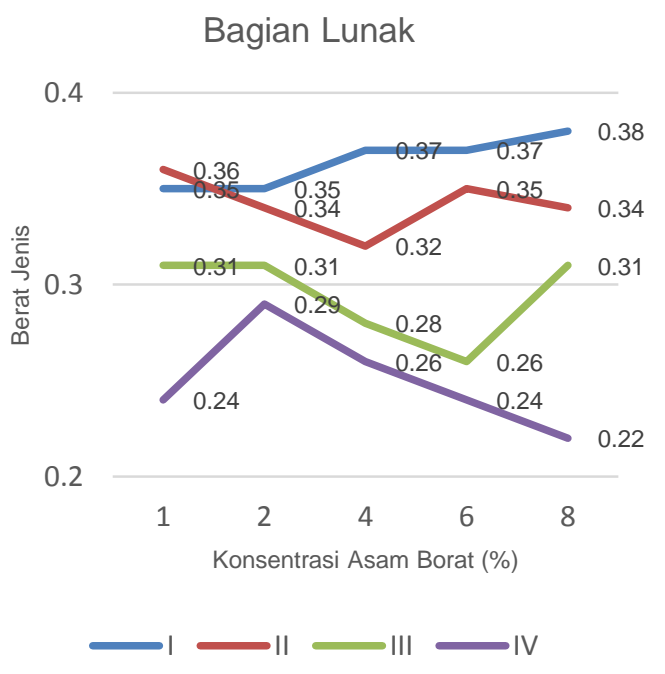

B

Gambar 4. Pengaruh Konsentrasi Asam Borat sebagai bahan perendam terhadap berat jenis papan dan bingkai reng dari $(A)$ bagian keras kayu aren, $(B)$ bagian lunak kayu aren

Hasil analisis berat jenis contoh uji papan dan bingkai reng batang aren yang menggunakan bahan pengawet asam borat dengan rendaman dingin (Gambar 4) 
menunjukkan bahwa bagian keras nilai berat jenis yang tertinggi diperoleh pada contoh uji I dengan ukuran panjang 1,5 meter dari pangkal batang aren dengan menggunakan konsentrasi bahan pengawet $8 \%$ yaitu sebesar 0,66 dan yang terendah diperoleh pada contoh uji IV dengan ukuran panjang 3 meter atau 6-9 meter dari dasar batang aren yang menggunakan bahan pengawet asam borat $1 \%$ yaitu senilai 0,46 dan bagian lunak hasil berat jenis yang tertinggi diperoleh pada contoh uji I dengan ukuran panjang 1,5 meter dari pangkal batang aren dengan konsentrasi bahan pengawet asam borat $8 \%$ yaitu sebesar 0,38 dan yang terendah diperoleh pada contoh uji IV dengan ukuran panjang 3 meter atau 6-9 meter dari pangkal batang aren dengan konsentrasi bahan pengawet asam borat $1 \%$ yaitu sebesar 0,24 .

Tinggi dan rendahnya nilai berat jenis contoh uji papan dan bingkai reng batang aren disebabkan oleh adanya struktur serat atau susunan serat yang tidak sama rata sehingga nilai berat jenis menurun dari pangkal keujung batang aren (9).

\section{Kuat Tekan Sejajar Serat $\left(\mathrm{kg} / \mathrm{cm}^{2}\right)$}

Hasil analisis kuat tekan sejajar serat contoh uji papan dan bingkai reng batang aren yang menggunakan bahan pengawet asam borat dengan rendaman dingin dapat dilihat pada Gambar 5.
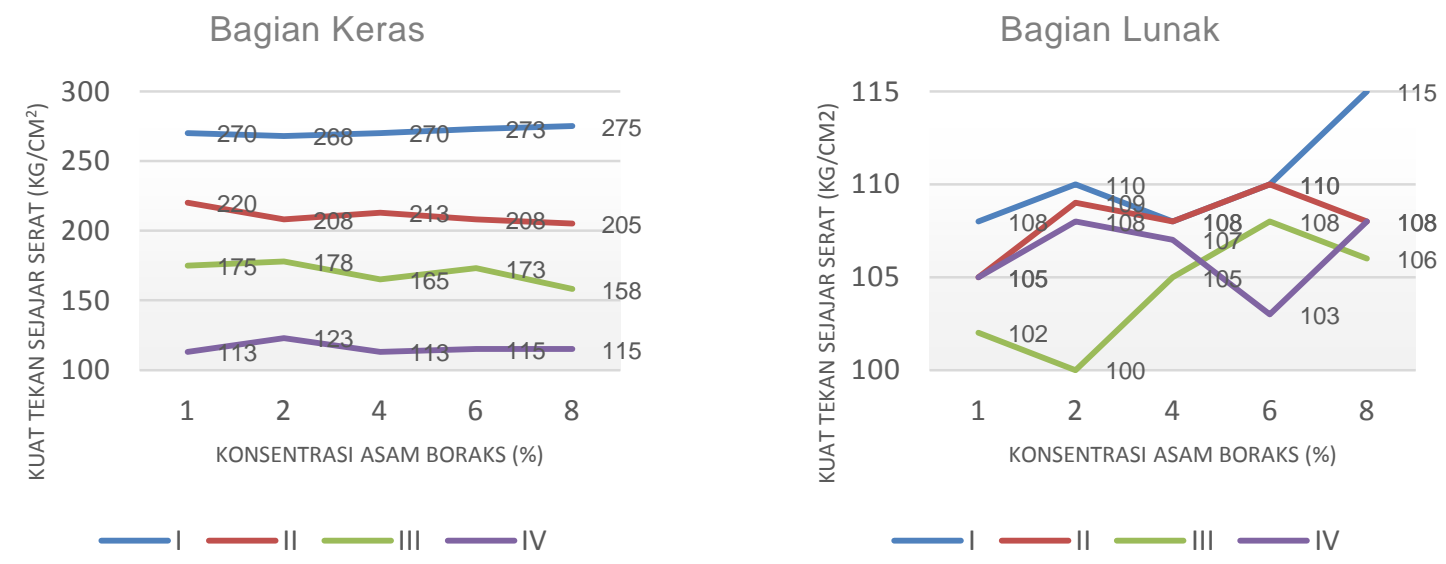

Gambar 5. Pengaruh Konsentrasi Asam Borat sebagai bahan perendam terhadap kuat tekan sejajarserat $\left(\mathrm{kg} / \mathrm{cm}^{2}\right)$ papan dan bingkai reng dari (A) bagian keras kayu aren, (B) bagian lunak kayu aren

Hasil analisis kuat tekan sejajar serat contoh uji papan dan bingkai reng batang aren yang menggunakan bahan pengawet asam borat dengan rendaman dingin (Gambar 5) menunjukkan bahwa bagian keras hasil kuat tekan sejajar serat yang tertinggi diperoleh pada contoh uji I dengan ukuran panjang 1,5 meter dari pangkal batang aren yang menggunakan bahan pengawet asam borat $8 \%$ yaitu sebesar $275 \mathrm{~kg} / \mathrm{cm}^{2}$ dan yang terendah diperoleh pada contoh uji IV dengan ukuran panjang $3 \mathrm{~m}$ atau 6-9 meter dari pangkal batang aren yang menggunakan bahan pengawet asam borat $1 \%$ yaitu sebesar $113 \mathrm{~kg} / \mathrm{cm}^{2}$ dan bagian lunak hasil kuat tekan sejajar 
serat yang tertinggi diperoleh pada contoh uji I dengan ukuran panjang 1,5 meter dari pangkal batang aren yaitu sebesar 115 $\mathrm{kg} / \mathrm{cm}^{2}$ dan yang terendah diperoleh pada contoh uji IV dengan ukuran panjang 3 meter atau 6-9 meter dari pangkal batang aren yaitu sebesar $105 \mathrm{~kg} / \mathrm{cm}^{2}$.

Tinggi dan rendahnya hasil kuat tekan sejajar serat disebabkan oleh adanya serat miring atau cacat kayu dimana dimana arah serat kayu yang berada pada sisi lebar mengarah kesisi tebalnya sehingga pada waktu ditekan kekuatan kayu tidak merata dan juga kayu batang aren dengan sel serabut yang sedikit dan dinding selnya sangat tipis serta mempunyai sifat dan mekanik yang lemah sehingga tidak kuat untuk menahan beban yang berat (10).

\section{Kuat Tekan Tegak Lurus Serat $\left(\mathrm{kg} / \mathrm{cm}^{2}\right)$}

Hasil analisis kuat tekan tegak lurus serat contoh uji papan dan bingkai reng batang aren yang menggunakan bahan pengawet asam borat dengan rendaman dingin dapat dilihat pada Gambar 6.

\section{Bagian Keras}

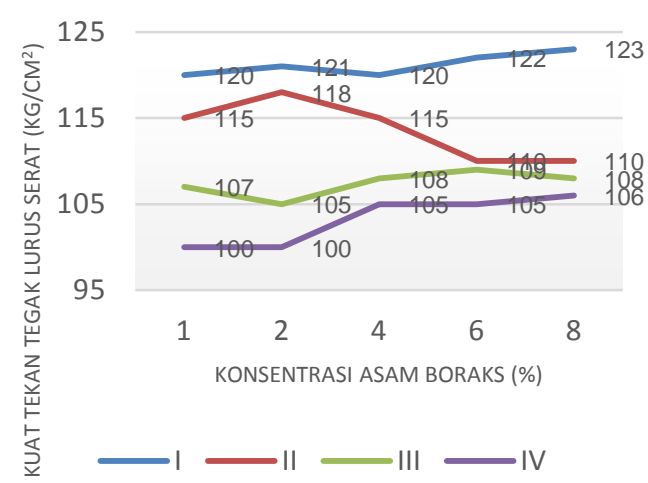

A
Hasil analisis kuat tekan tegak lurus serat contoh uji papan dan bingkai reng batang aren yang menggunakan bahan pengawet asam borat dengan rendaman dingin (Gambar 6) menunjukkan bahwa bagian keras hasil kuat tekan tegak lurus serat yang tertinggi diperoleh pada contoh uji I dengan ukuran panjang 1,5 meter dari pangkal batang aren dengan menggunakan bahan pengawet $8 \%$ yaitu sebesar 123 $\mathrm{kg} / \mathrm{cm}^{2}$ dan yang terendah diperoleh pada contoh uji IV dengan ukuran panjang 3 meter atau 6-9 meter dari pangkal batang aren yaitu sebesar $100 \mathrm{~kg} / \mathrm{cm}^{2}$, sedangkan bagian lunak hasil kuat tekan tegak lurus serat yang tertinggi diperoleh pada uji contoh I dengan ukuran panjang 1,5 meter dari pangkal batang aren yang menggunakan bahan pengawet asam borat $8 \%$ yaitu sebesar $110 \mathrm{~kg} / \mathrm{cm}^{2}$ dan yang terendah diperoleh pada contoh uji IV dengan ukuran panjang 3 meter atau 6-9 meter dari pangkal batang aren dengan menggunakan bahan pengawet asam borat $1 \%$ yaitu sebesar $75 \mathrm{~kg} / \mathrm{cm}^{2}$.

Gambar 6. Pengaruh Konsentrasi Asam Borat sebagai bahan perendam terhadap kuat tekan tegak lurus $\left(\mathrm{kg} / \mathrm{cm}^{2}\right)$ papan dan bingkai reng dari (A) bagian keras kayu aren, (B) bagian lunak kayu aren 
Tinggi dan rendahnya hasil kuat tekan tegak lurus serat atau cendrung menurun, hal ini disebabkan karena arah serat batang aren adalah radial artinya susunan serat satu arah sehingga pada waktu ditekan beban mengarah sesuai arah serat dan tebal contoh uji (11).

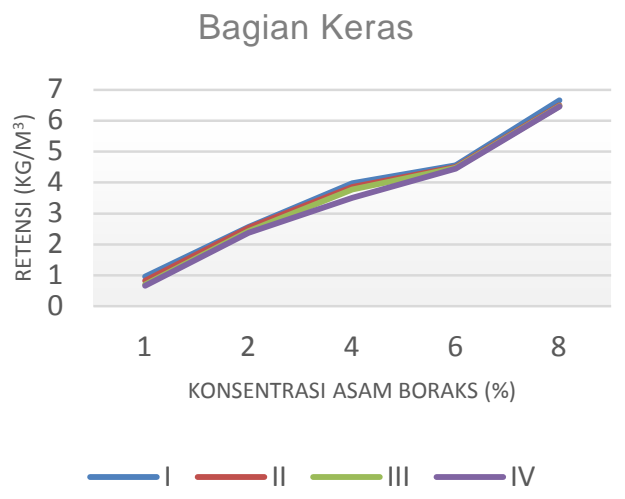

A
Retensi

Hasil analisis retensi contoh uji papan dan bingkai reng batang aren yang menggunakan bahan pengawet asam borat dengan rendaman dingin dapat dilihat pada Gambar 7.

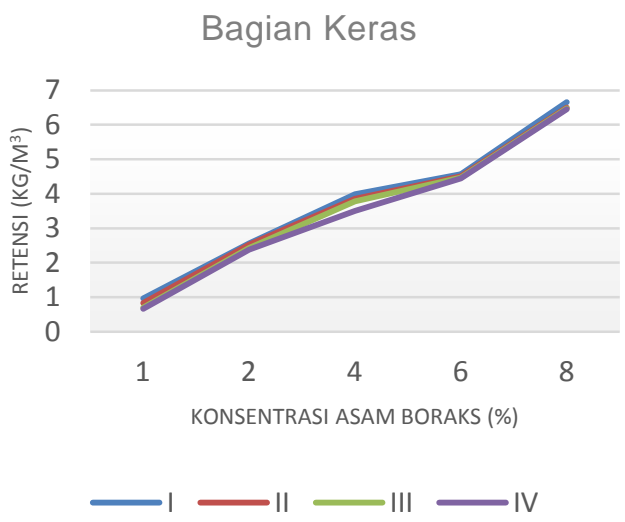

B

Gambar 7. Pengaruh Konsentrasi Asam Borat sebagai bahan perendam terhadap retensi (kg/m3) papan dan bingkai reng dari (A) bagian keras kayu aren, (B) bagian lunak kayu aren (\%)

Hasil analisis retensi contoh uji papan dan bingkai reng batang aren yang menggunakan bahan pengawet asam borat dengan rendaman dingin (Gambar 7) menunjukkan bahwa bagian keras hasil retensi yang tertinggi diperoleh pada contoh uji I dengan ukuran panjang 1,5 meter dari pangkal batang aren dengan menggunakan bahan pengawet asam borat $8 \%$ yaitu sebesar $6,65 \mathrm{~kg} / \mathrm{m}^{3}$ dan yang terendah diperoleh pada contoh uji IV 3 meter atau 69 meter dari pangkal batang aren yaitu sebesar $0,66 \mathrm{~kg} / \mathrm{m}^{3}$ dan bagian lunak retensi yang tertinggi diperoleh pada contoh uji I dengan ukuran panjang 1,5 meter dari pangkal batang aren yaitu sebesar 5,53 $\mathrm{kg} / \mathrm{m}^{3}$ dan yang terendah diperoleh pada contoh uji IV dengan ukuran panjang 3 meter atau 6-9 meter dari pangkal batang aren yaitu sebesar $0,29 \mathrm{~kg} / \mathrm{m}^{3}$. Tinggi dan rendahnya atau menurunnya retensi yang diperoleh disebabkan oleh pengaruh kadar air yang tinggi, mengakibatkan retensi akan menurun karena rongga atau dinding selulosa tertutup dengan air sehingga bahan pengawet sulit masuk kedalam kayu batang aren dan menempel pada dinding luar (12).

\section{Penetrasi}

Hasil analisis penetrasi contoh uji papan dan bingkai reng batang aren yang menggunakan bahan pengawet asam borat dengan rendaman dingin dapat dilihat pada Gambar 8. 
Bagian Keras

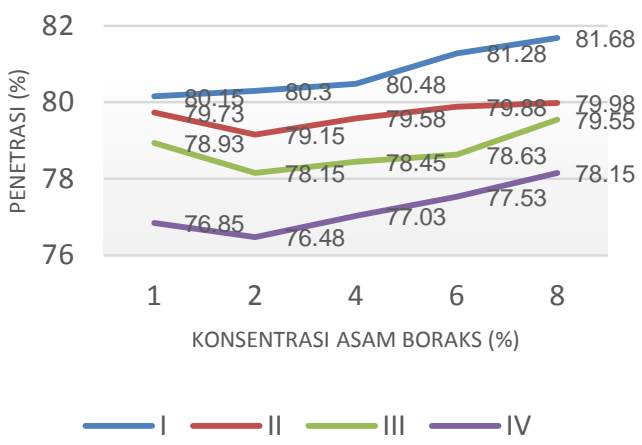

A
Bagian Lunak

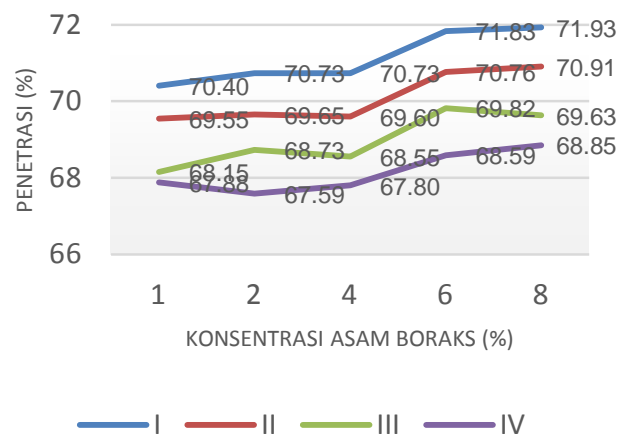

B

Gambar 8. Pengaruh Konsentrasi Asam Borat sebagai bahan perendam terhadap penetrasi (\%) papan dan bingkai reng dari $(A)$ bagian keras kayu aren, $(B)$ bagian lunak kayu aren (\%)

Hasil analisis penetrasi contoh uji papan dan bingkai reng batang aren yang menggunakan bahan pengawet asam borat dengan rendaman dingin (Gambar 8) menunjukkan bahwa bagian keras hasil penetrasi yang tertinggi diperoleh pada contoh uji I dengan ukuran panjang 1,5 meter dari pangkal batang aren dengan konsentrasi bahan pengawet $8 \%$ yaitu sebesar $81,68 \%$ dan yang terendah diperoleh pada contoh uji IV dengan ukuran panjang 3 meter atau 6-9 meter dari pangkal batang aren yaitu sebesar $76,85 \%$. Bagian lunak hasil penetrasi yang tertinggi diperoleh pada contoh uji I dengan ukuran panjang 1,5 meter dari pangkal batang arenyaitu sebesar $71,93 \%$ dan yang terendah diperoleh pada pada contoh uji IV dengan ukuran panjang 3 meter atau 6-9 meter dari pangkal batang aren yaitu sebesar $67,88 \%$.

Tinggi dan rendahnya hasil penetrasi yang diperoleh disebabkan oleh struktur anatomi dan serat dari batang aren atau contoh uji dan juga diduga oleh kandungan kadar air yang tinggi yang mengakibatkan pori-pori atau dinding selulosa tidak terbuka sempurana pada waktu perendaman (13).

\section{KESIMPULAN}

Hasil penelitian ternyata bahwa batang aren dapat diproses menjadi papan dan bingkai reng menjadi bahan bangunan dengan kisaran yaitu: 0-1,5; 1,5-3,5; 3,5-6 dan 6-9 meter dari pangkal batang aren.

Bagian batang aren yang diproses menjadi bahan bangunan menunjukkan bahwa Bagian keras dengan rendaman dingin memberikan hasil kisaran yaitu kadar air $14,17-19,91 \%$, nilai berat jenis 0,460,66 , kuat tekan sejajar serat $113-275$ $\mathrm{kg} / \mathrm{cm}^{2}$, kuat tekan tegak lurus serat 100 $123 \mathrm{~kg} / \mathrm{cm}^{2}$, retensi 0,66-6,65 $\mathrm{kg} / \mathrm{m}^{3}$, penetrasi $76,85-81,68 \%$ dan bagian lunak kadar air 16,30-21,48\%, nilai berat jenis $0,24-0,38$, kuat tekan sejajar serat 105-115 $\mathrm{kg} / \mathrm{cm}^{2}$, kuat tekan tegak lurus serat 75 - 
$110 \mathrm{~kg} / \mathrm{cm}^{2}$, retensi $0,29-3,53 \mathrm{~kg} / \mathrm{m}^{3} \mathrm{dan}$ penetrasi $67,88-71,93 \%$.

Hasil penelitian ternyata bahwa perlakuan yang terbaik diperoleh pada contoh uji I dengan ukuran 1,5 meter dari pangkal batang aren dengan menggunakan bahan pengawet asam borat $8 \%$ yaitu rendaman dingin karena menghasilkan kuat tekan sejajar serat yang tertinggi 275 $\mathrm{kg} / \mathrm{cm}^{2}$, penetrasi $93,45 \%$, retensi 8,00 $\mathrm{kg} / \mathrm{m}^{3}$ berat jenis 0,68 dan memenuhi standar mutu kayu bangunan SNI 03-35271994.

\section{DAFTAR PUSTAKA}

1. Akuba. Profil Aren. Seminar Nasional Aren. Tondano: Balai Penelitian Tanaman Kelapa dan Palma Lain;

2. Biro Pusat Statistik Provinsi Sulawesi Utara. Sulut Dalam Angka. Biro Pusat Statistik Provinsi Sulawesi Utara; 2009.

3. Pebryan P. Potensi Tanaman Aren dan Turunannya [Internet]. 2012. Available from: http/c:/user/favirites/ potensitanamanaren

4. Ridwan B. Syarat Mutu Kayu Bangunan SNI 03-3527-1994. 2006.

5. Barly. Standardisasi Pengawetan Kayu dan Bambu Serta Produknya. PPI Standardisasi. Jakarta: Pusat Penelitian dan Pengembangan Hasil Hutan;
6. Mardikanto TR, Karlinasari L BE. Sifat Mekanis Kayu. Bogor: Departemen Hasil Hutan Fakultas Kehutanan IPB; 2009.

7. SNI 03-5010-1999. Pengawetan Kayu Untuk Perumahan dan Gedung.

8. Maman M, I. Susanto, A. Fathini T. Rayap: Biologi dan Pengendaliannya. Pengolahan Hasil Hutan. Surakarta: Badan Litbang Kehutanan Kementerian Kehutanan Jakarta; 2010.

9. Karlinasari, L. Wahjuna, M.E. Nugroho N. Non Destrutive Ultrasonic Testing Method for Determining Bending Strength Properties of Gmelia Wood. J Trop For Sci. 2008;20(2):99-104.

10. Kasmudjo. Teknologi Hasil Hutan. Yogyakarta: Cakrawala Media; 2010.

11. Lebow, S.P. Halverson S. Penetration of Boron from Topically Applied Borate Solution Forest Products Journal. 2010;

12. Anonim. Manual Bahan Pengawetan Diffusol-CB. Kuala Lumpur: KoppersHickson Timber Malaysia; 2008.

13. Yamauchi, SY. Sakai, Y. Waanabe. M K. Distribution Boron Inwood Treated With Aqeous and Methanolic Boric Acid Solutions. J Wood Sci. 2000;53:324-31. 